\title{
England, whose England?
}

Stuart Sillars

Sometimes it seems that the most peculiarly English quality among the English is the constant neurosis that forces it to define its own identity. The current manifestation with leaving the EU is only the latest, although possibly the most disastrous, sign of this. It is apparent even in the dreadful linguistic colonisation of 'Brexit' which, apart from sounding like an unhealthy breakfast serial, makes no grammatical sense at all to anyone with even the smallest knowledge of Latin: shouldn't that be 'Brexamus', unless it is restricted to one person's departure? The word is now described as English - but only in the way that other coinages and appropriations are quaintly described as 'loan words', as if due for return at some distant lexical judgment day. With an irony as yet unremarked, the word itself combines syllables of Old French and classical Latin, an etymological undermining of the word's apparent purpose. These matters - the neurosis, and its political and linguistic expressions - are given detailed and imaginative critical form in a recent volume of essays, Continental Perceptions of Englishness, 'Foreignness' and the Global Turn, by Adriana Neagu. ${ }^{1}$ Built around a series of articles and interviews, it explores the notion of Englishness and its contemporary manifestations, concentrating mainly on Peter Ackroyd but also discussing the work of Kashio Ishiguro and touching on the complexities of translation.

The relevance of this discussion to Renaissance studies is strong, where the idea of national identity is similarly ambivalent. In visual art, the English repeatedly deny or obscure the extensive involvement of European nations within what are often, and inaccurately, described as 'iconic' works. Many of the finest ecclesiastical paintings - the rood screens, retables and wall paintings that remain, often in remote churches of East Anglia - might well 
be the work of French or Netherlandish artists. The finest royal devotional object of the fourteenth century, the Wilton Diptych, may well be the work of a mainland European figure - its origin is currently described as 'French or English.' John Dowland, whose music for lute or voice is now justly celebrated, was a court musician not in England but in Denmark; his melancholy was far more widely accepted than those who claim it as a uniquely English affliction would like to believe. The finest plasterwork in Elizabethan great houses drew extensively on continetal European patterns, mainly from the Netherlands, and was perhaps also executed by overseas craftsmen.

Shakespeare has been one of the most recurrent victims of such nervousness, not least in The Elizabethan World Picture, that sub-Biblical narrative on which so much scholarship rested from the forties to the sixties of the last century. Arguing that the structure of rank was as rigid in the early seventeenth century as in previous decades, it suggests a fabric of hierarchy that is unchallenged in the plays, seeing it as a central element of English identity, and never accepting the possibility that Shakespeare might have been using the concept well, if not quite satirically, then at least surrounded by questions. First published in 1943, the volume is not, of course, free from temporal as well as geosocial inflection. But times are altered. The famed 'Take but degree away' speech from Troilus and Cressida, still read by eager undergraduates as a philosophical and practical tourist guide to early seventeenthcentury England, must be seen as tempered by events not just in England but throughout Europe.

Think, too, of the way we organise the plays. Histories are still often presented in order of composition, facilitating their reading as chronicles of Tudor providentialism whereas the first tetralogy, with the loss of Calais and the death of Henry VI, powerfully denies such firm national progression. Many of Shakespeare's audience, of course, would 
have seen or known of these plays when seeing the later ones; knowing subsequent events, they would surely not have seen Henry $V$ as a glorious conclusion. The epilogue of Henry $V$, stressing the later failure of the kingdom, is rarely included in production. Kenneth Branagh's film version, for all its technicolour realism, offers as much glory as gore. Through any and all such approaches, the plays' processes and their generic complexities are blunted, if not wholly obscured. That the plays were, until at least the middle of the last century, seen as a parallel version of English history, and for many the route more often taken in its assimilation, adds further complication.

We talk of 'the Roman Plays' without considering them as equally historic, and equally if not more explosive in their political relevance to the time of writing and performance. And why define these alone by their place of action? The one exception is Macbeth, known as 'the Scottish Play', but only because of theatrical superstition. Ironically, when seen alongside the English histories its main driving force becomes much clearer than evidenced in the debates about gender power and the Lady as the fourth witch. Duncan is pretty obviously a very bad king, who deserves his deposition, as becomes apparent much earlier, and much more obviously to the other roles, than does Richard III. Calling the comedies 'the Italian Plays' makes a lot more sense, rendering audible the skill with which they absorb and re-cast Italian models from Machiavelli to Guarini. Scholars will know this; but for the public - those for whom the major theatres patronisingly make the plays 'accessible' - they are celebrated, along with the canon as a whole, because they reveal Shakespeare's innate Englishness as 'The Swan of Avon' or 'The Bard'. And, of course, the understanding of human nature the plays offer is assumed to rest firmly on his being English - the model against which all humanity is measured. 
At a time when the nature of Englishness is enshrined in much political manoeuvring and some very dubious legislation, as well as explosive headlines in the Daily Mail (the cardiologist's friend), and is the subject of debate at too many levels to list, these issues assume an importance far beyond theatre and study. Part of this are the volumes discussing the symptoms of Englishness by luminaries as varied as Jeremy Paxman and Stephen Fry, offering a range of stances, values and insights. Among them, Stefan Collini's English Pasts remains exceptional, particularly when paired with his more specialised volume, the exhilarating yet depressing Absent Minds: Intellectuals in Britain.

A more insistent, more faceted, effort comes from a writer both popular in the best sense and scholarly: Peter Ackroyd. Neagu's discussions provide a cross-section through present attitudes, a microscope slide for larger analysis of the near-clinical appeal such deliberations still hold. That the collection is by a scholar working in Romania, whose graduate study was completed in Scandinavia, salts the writing with intellectual caution and breadth. Its foreword declares directly that this is a collection of essays published elsewhere, dating back to 2003, with no effort to bind them into a whole - a decision that allows the development of ideas over a decade, for the reader to relate and extend. At times its continental European is powerfully apparent, for example in the opening chapter on the theoretical bases of 'the Translatability of Cultures', reminding readers - Scandinavian, Romanian, English- that, however much some readers may dislike the fact, there is a world elsewhere. This is an address to the problems of translation, glancing across concepts and quotations from significant theorists. The second chapter continues in the same manner, summarising problems of reconciliation between translation as a theoretical debate and an economic and commercial service, ending with a quotation from Derrida that all translation ends in 'primal confusion'. 
There are some valuable allusions and quotations here, not least Brodsky's remark that English readers are consuming not Tolstoy and Dostoyevsky but Constance Garnet. True, of course; but I wonder if the difficulty generates as many positives as negatives. That many Penguin translations of the fifties seemed to read as though placed within a single vocabulary certainly made them accessible to eager readers, of whom I was one, offering at least some point of departure and comparison in a Victorian Novel examination paper. But the assertions might have been softened by looking at more recent translations (Garnet's date from early in the last century, some even before) and more recent ones have striven for greater closeness. The same is true for treatments of Proust, Camus, and most recently many novelists and poets from Eastern Europe. The poems of the Hungarians Miklós Rodnóti and Györgi Petri, by the native speaking poet George Gömöri with the English poet Clive Wilmer, offer an invigorating present-day extension to Renaissance projects of the nature of the Earl of Surrey's Aeneid Books two and four, arguably the first continuous use of unrhymed iambic pentameter in English, or the massive work of Sir Thomas Harington's complete translation of Orlando Furioso. From a Romanian standpoint, too familiar for those who know to need mention, translation is a frequent part of graduate studies - a Donne sonnet to honour a retiring academic, say, or a complete novel from Paul Auster.

In the sixteenth century many works were presented as being not translated but 'English'd', a process of transculturation rather than word-pairing, and thus a valuable reversal of the limitations raised by Brodsky and Neagu. Coverdale's Psalms, while diverging widely from Hebrew originals, have a resonance and immediacy that gives them great force to their contemporary, as well as present-day, readers; and they also spawned what is probably the only wholly English musical form, still vibrant today, Anglican chant. The King James Bible, completed in a magical occasion when its translators read aloud the passages 
assigned to them, to hear and discuss their use of the English tongue, surely contributes much to the contemporary beauty of holiness. Did such endeavours lead to silence and confusion, or to a new order of textual parallelism at least as valuable as something aiming for, to paraphrase Eliot, a condition of perfect equivalence? Questions like this are not explicit in the book; but any thoughtful reader will be led towards them by their unspoken implication.

One of the sharpest chapters addresses 'Anglo-Centric Attitudes.' The title alone, rich in literary echoes, goes a long way towards destabilising the superficial concept of Englishness as a single condition, instantly recognisable and anxiously protected by legislation. Parallels with earlier situations of change are appealing, fraught with dangers of misalliance but nonetheless suggestive of recurrent concerns within the nation - or nations, indeed. The salient text here is Michael Drayton's Polyolbion, not least in its full title:

Poly-Olbion. or A chorographicall description of tracts, riuers, mountaines, forests, and other parts of this renowned isle of Great Britaine : with intermixture of the most remarquable stories, antiquities, wonders, rarityes, pleasures, and commodities of the same: digested in a poem by Michael Drayton, Esq. With a table added, for direction to those occurrences of story and antiquitie, whereunto the course of the volume easily leades not.

The book's publication in 1612 is almost as illuminating. The inclusion of Scotland by the accession of James II to the English throne has by then become, if not fully acceptable, then at least the product of a peace of some kind. Later battles and skirmishes have had only uneasy resolution, and the underlying fear, in England, of a rekindled Jacobitism, still lingers; strikes of Glasgow shipbuilders in the 14-18 war, dissent among the newly devolved Scottish 
parliament, are only two instances of its resurgence. These are sombre pedal notes beneath the apparent harmonies of the two states; again, any reader aware of the longer path will hear this under and within Neagu's discussions.

The same is true of an earlier, today little-read, book of Drayton's:

Englands heroicall epistles. By Michaell Drayton / [By Drayton, Michael 1563-1631.]

At London : Printed by I[ames] R[oberts] for N. Ling, and are to be sold at his shop at the vvest doore of Poules 1597

That 'vvest doore of Poules' is suggestive in another way. St Paul's Churchyard was the centre of activity for stationers of the day, for publication as well as sale of books. But here it has special resonance. The epistles are English, not British, and within this is contained a pattern of national folk lore and belief, something not at all the same as the more inclusive naming. The book itself make this clear by omission as much as inclusion: no Hibernians receive the accolade within the book's covers. The epistles themselves, a series of verse letters between royal personages and their enamorata devised by Drayton himself, give greater force to their supposed writers. The book's opening 'To the reader' describes them as 'them for whom the greatness of minde come neare to Gods'. The placement alongside classical figures again reveals a forceful, and still recurrent, English amour-propre.

The publication details also reveal much about the centrality of the capital to publishing, but less directly suggest its placement, physical, intellectual and ultimately spiritual, within the nation. Later passages in Neagu's book reveal a similar breadth of concern in Ackroyd's discussions of London. The very title of his book on the capital, London: the Biography, reveals a concern for the city as organism, constantly present and 
repeatedly re-inventing itself. Its earlier incarnations are made explicit in Ackroyd's House of Doctor Dee, gathering philosophical, alchemical and political forces as microcosmic of London; and also, in an astute quotation from Neagu's discussion, the line from Coriolanus: 'what is the city but the people?' Similar forces are united in the discussion of Thames: Sacred River, in which Neagu presents Ackroyd's view of the waterway's 'essences and continuities' as 'sacred space', in itself and of the city through which it runs. It is here that Ackroyd himself moves closest to a renaissance imagination, the London that made possible Jonson's dark comedies - the frenetic, contorted plot of The Alchemist a parallel to the city's energy, and Jacobean city comedy and tragedy offering its obverse and reverse sides with similar force.

Later passages in the book move towards more general themes. Most extensive is an exploration of a different kind of Englishness in the works of Kashio Ishiguro, relating it to kinds of post-colonial theory but concluding that, ultimately, the writing explores Eliot's idea: 'the more national, the more universal'. But if Ishiguro is writing from a more distant perspective, then perhaps there is an irony that escapes its discussion here: The Remains of the Day grew out of the first Master's course in creative writing to be taught in an English university. Whether the foundation of what is now a thriving - and very lucrative - tradition in English academies is another instance of isolationism, or a demonstration of European and American influence, who can say?

The final essay bemoans the frequent use among English intellectuals of the word 'European' as wholly foreign, while overlooking the fact of England's place within the continent, seeing it as another endemic example of the island-state's mixture of arrogance and uncertainty. And, of course, it again mirrors an outlook that flourished in the sixteenth and seventeenth centuries. In The Unfortunate Traveller Thomas Nashe could write splenetically 
about the ingenious orders of corruption that existed in Italy, while praising the nation's force in literature. The imaginative reconstruction of Italian poetry and drama by Shakespeare and others is subtler in effect and form, but reveals a similar ambivalence of attitude.

While this discussion has read Continental Perceptions very much by exploring its parallels to an earlier age, its values as a present-day exploration should not be undervalued. The collection addresses issues that remain insistent today, constantly and bewilderingly resurfacing in what, to borrow a phrase of the great Tom Lehrer, might well be called the masochism tango of Brexit. That the discussion is rooted in secure and wide-ranging awareness of many branches of central European literary theory is another of its strengths; and lest that be thought of as an achievement manifestly unEnglish, its presentation of the authors' own voices, through extensive interviews with both Ackroyd and Ishiguro, offers further depth and balance to this provocative and immediate collection. As an approach to Ackroyd's writings, it is perceptive and wide-ranging; in its larger implications about the historical forces at work within notions of nationhood, it presents a voice powerfully resonant.

One comment from the author about Ackroyd's approach might well be taken as a summary of the whole debate, in relation to his own writing, the present state of the discussion and its long, earlier travels from medieval Norfolk to contemporary Brick Lane. Discussing the place of Catholicism in a protestant nation, Ackroyd's approach is both distanced and inclusive, 'versatility being his algorithm of Englishness'. As approaches go, that seems the best we can do, as both a summary of past practice and a pious hope for the future.

\footnotetext{
${ }^{1}$ Newcastle-upon-Tyne: Cambridge Scholars, 2017.
} 